\title{
TENDENCJE W ZARZĄDZANIU DLUGIEM SAMORZĄDOWYM W POLSCE NA PODSTAWIE WIELOLETNICH PROGNOZ FINANSOWYCH JEDNOSTEK SAMORZĄDU TERYTORIALNEGO
}

\section{WPROWADZENIE}

Zarządzanie długiem stało się niezwykle ważnym elementem zarządzania finansami w jednostkach samorządu terytorialnego (jst). Jest to spowodowane przede wszystkim istotnym i trwałym wzrostem zadłużenia samorządowego, którego przyczyn należy upatrywać przede wszystkim w możliwości wykorzystania środków unijnych, wymagającej udziału jednostki we współfinansowaniu określonego projektu, a także w rosnących oczekiwaniach społeczności lokalnych na działania rozwojowe prowadzone w skali lokalnej i regionalnej. Wzrost zadłużenia samorządowego, stanowiącego część państwowego długu publicznego, zwiększył zainteresowanie władz centralnych tym problemem, skutkiem czego było wprowadzenie nowych regulacji w tym zakresie.

Ustawa z 27 sierpnia 2009 r. o finansach publicznych wprowadzono przede wszystkim nowy sposób limitowania zadłużenia, który uzależnia zdolność jednostki do zaciaggania długu od możliwości kreowania przez nią nadwyżek finansowych. Działania te miały na celu, jak się wydaje, przede wszystkim ograniczanie dalszego, tak dynamicznego wzrostu zobowiązań samorządów ${ }^{1}$. Zmieniły one sposób zarządzania finansami jednostek, w szczególności ich zobowiązaniami. Ponadto ustawodawca wprowadził obowiązek formułowania przez jednostki planów finansowych pod postacią wieloletniej prognozy finansowej, w której muszą znaleźć się przewidywania najważniejszych kategorii

${ }^{1}$ Nowy limit zadłużenia, zapisany w art. 243 wskazanej ustawy, określa, że środki publiczne przeznaczane na obsługę długu jednostki w stosunku do jej dochodów ogółem w danym roku budżetowym nie mogą być większe niż średnia relacja nadwyżki operacyjnej powiększonej o dochody ze sprzedaży majątku do dochodów ogółem jednostki z ostatnich trzech lat. Z przeprowadzonych badań wynika, że nowe ograniczenie będzie przeciętnie bardziej rygorystyczne dla większości jednostek samorządu terytorialnego w Polsce, z wyjątkiem województw, niż limit obowiazujący do końca 2013 r., zapisany w art. 169 ustawy o finansach publicznych z 2005 r. Por. K. Marchewka-Bartkowiak, M. Wiśniewski, Indywidualny wskaźnik zadłużenia JST - ocena krytyczna i propozycje zmian, „Analizy BAS” 2012, nr 21, s. 4; P. Swianiewicz, J. Łukomska, Kto żyje na kredyt - ranking zadtużenia samorzadów, „Wspólnota” 2013, nr 19. 
finansowych jednostki, w tym także wielkości jej zadłużenia² . Od 2013 r. nowe obowiązi sprawozdawcze w zakresie wieloletniej prognozy finansowej (forma elektroniczna) zapewniły Ministerstwu Finansów łatwy i szczegółowy wgląd w politykę zadłużenia jednostek. Publikowanie przez ministerstwo całościowych zestawień prognoz finansowych samorządów umożliwiło po raz pierwszy przeprowadzenie analizy planowania zadłużenia samorządowego w takiej skali. W niniejszym artykule autorzy podjęli próbę wskazania tendencji, jakie można zaobserwować w polityce zarządzania długiem jednostek. W szczególności przeanalizowano plany dotyczące wielkości zadłużenia, w podziale na szczeble samorządu terytorialnego, w ujęciu bezwzględnym, jak i względnym, oraz obsługę zadłużenia, uwzględniając tworzenie przyszłego długu i jego spłatę, a także koszty zaciagniętych zobowiązań.

\section{PODSTAWY ZARZĄDZANIA DEUGIEM W JEDNOSTCE SAMORZĄDU TERYTORIALNEGO}

Wykonywanie zadań powierzonych jednostkom samorządu terytorialnego wymaga przede wszystkim pozyskania środków finansowych na ich realizację. Zarządzanie finansami samorządu można określić jako proces, który polega na podejmowaniu przez organ stanowiący i wykonawczy jednostki wzajemnie powiązanych działań i decyzji służących maksymalizacji ekonomicznych i społecznych efektów, zgodnie z przyjętymi celami bieżącymi i strategicznymi ${ }^{3}$. Innymi słowy, jest to kompleksowe zarządzanie zasobami finansowymi, którego celem jest wykonywanie założeń polityki finansowej, określającej dobór źródeł i metod gromadzenia środków publicznych oraz kierunków i sposobów ich wydatkowania dla osiagnięcia przyjętych celów .

Do środków publicznych zalicza się także przychody, w tym te, które maja charakter zwrotny ${ }^{5}$, a których wykorzystanie powoduje powstanie długu jednostki. Środki te maja kluczowe znaczenie w finansowaniu inwestycji samorządowych, w tym także tych współfinansowanych z pozyskanych środków pomocowych Unii Europejskiej, dlatego też uznaje się, że zarządzanie długiem

\footnotetext{
${ }^{2}$ Przed 2010 r. zarząd jednostki sporządzał osobną prognozę łącznej kwoty długu na rok budżetowy i lata następne, a obecnie stała się ona integralną częścią wieloletniej prognozy finansowej.

${ }^{3}$ H. Sochacka-Krysiak (red.), Zarzadzanie gospodarka $i$ finansami gminy, Wydawnictwo Szkoły Głównej Handlowej w Warszawie, Warszawa 2003, s. 161.

${ }^{4}$ M. Jastrzębska, Zarzqdzanie długiem jednostek samorzqdu terytorialnego, Wydawnictwo Wolters Kluwer, Warszawa 2009, s. 72.

${ }^{5}$ Według prawa są to przede wszystkim środki służące sfinansowaniu deficytu budżetowego jednostki, którymi są: kredyty i pożyczki zaciagnięte przez jednostkę oraz środki ze sprzedaży wyemitowanych przez jednostkę papierów wartościowych (ustawa z 27 sierpnia 2009 r. o finansach publicznych, Dz. U. Nr 157, poz. 1240, art. 217 ust. 2), a także inne umowy wpływające na poziom długu (np. umowy leasingu, umowy z zakresu partnerstwa publiczno-prywatnego, umowy sprzedaży ratalnej) dookreślone przez Ministra Finansów (rozporządzenie Ministra Finansów z 28 grudnia 2011 r. w sprawie szczegółowego sposobu klasyfikacji tytułów dłużnych zaliczanych do państwowego długu publicznego, Dz. U. Nr 298, poz. 1767).
} 
jest na tyle istotnym zagadnieniem zarządzania finansami, że wymaga przyjęcia lokalnej strategii zarządzania długiem ${ }^{6}$. Na proces zarządzania długiem składają się następujące elementy ${ }^{7}$ :

- planowanie poziomu zadłużenia jednostki w zależności od potrzeb finansowych i zdolności do obsługi długu,

- organizowanie (techniczne przeprowadzenie czynności związanych z zaciąganiem zobowiązań),

- motywowanie (przejawiające się stworzeniem zespołu osób odpowiedzialnych za zarządzanie długiem),

- monitorowanie (ocena poziomu i struktury zadłużenia w powiąaniu z analizą skutków wykorzystania pozyskanych środków zwrotnych i możliwości dalszego zadłużania się),

- analiza obciążenia budżetu jednostki zobowiązaniami z tytułu obsługi długu,

- kontrola poziomu długu i dopasowywanie go ex ante i ex post do prawnych limitów zadłużenia.

Wykorzystanie zwrotnych źródeł finansowania zadań jednostki pozwala osiagnaćc wiele korzyści, ale także generuje szereg zagrożeń, dlatego też ważne jest, aby decyzję o zaciagnięciu zobowiązań poprzedziły analizy pozwalające na określenie możliwych rozmiarów długu, jego instrumentów, terminów spłaty oraz ponoszonych kosztów finansowych ${ }^{8}$. Sposobem i jednocześnie efektem prowadzenia takich analiz jest wieloletni plan finansowy. Jest on najważniejszym narzędziem zarządzania długiem, stanowiącym łącznik pomiędzy wymienionymi powyżej elementami procesu.

Przed 2010 r. wieloletnie planowanie finansowe w jednostkach samorządu terytorialnego miało charakter fakultatywny. Zmiany wprowadziła ustawa o finansach publicznych z 2009 r. Zapisy rozdziału 2 działu V definiuja obowiązkowy plan finansowy jednostki samorządu terytorialnego, którym jest wieloletnia prognoza finansowa $(\mathrm{WPF})^{9}$. W uchwale o WPF muszą znaleźć się co najmniej planowane na każdy rok objęty prognoza:

- dochody bieżące oraz wydatki bieżące budżetu jst, w tym na obsługę długu, gwarancje i poręczenia,

${ }^{6}$ M. Poniatowicz, J. M. Salachna, D. Perło, Efektywne zarzqdzanie dtugiem w jednostce samorzqdu terytorialnego, Wolters Kluwer, Warszawa 2010, s. 68-69.

${ }^{7}$ M. Jastrzębska, op. cit., s. 72.

${ }^{8}$ M. Bitner, K. S. Cichocki, J. Sierak, Standardy zarzqdzania dtugiem na szczeblu lokalnym i regionalnym oraz ich wptyw na finansowanie infrastruktury, Instytut Badań Systemowych PAN, Warszawa 2013, s. 33.

${ }^{9}$ Zdaniem autorów dokument ten pomimo swojej nazwy powinien być traktowany raczej jako plan finansowy, a nie prognoza. Sporządzane wcześniej przez jednostki dokumenty planistyczne nazywane były planami finansowymi, co wydaje się słuszniejszą (bardziej adekwatna) nazwą niż wprowadzona i obecnie stosowana „prognoza”. Etymologicznie prognoza jest sądem na temat przyszłości, który jest efektem prognozowania (predykcji), które z kolei jest naukowa metoda przewidywania przyszłych zjawisk. Nie można oczywiście odmówić niektórym planom finansowym naukowego charakteru, jednakże chociażby ze względu na fakt, iż są one formułowane na okres niekiedy nawet dłuższy niż 30 lat, trudno w tym przypadku mówić o wiarygodności prognozy oraz jej „realistyczności”, którą wymaga sam ustawodawca. 
- dochody majątkowe, w tym dochody ze sprzedaży majątku, oraz wydatki majątkowe budżetu jst,

- wynik budżetu jednostki samorządu terytorialnego,

- przeznaczenie nadwyżki albo sposób sfinansowania deficytu,

- przychody i rozchody budżetu jednostki samorządu terytorialnego, z uwzględnieniem długu zaciagniętego oraz planowanego do zaciagnięcia,

- kwotę długu jednostki samorządu terytorialnego, w tym relację zapisaną indywidualnym wskaźnikiem zadłużenia, oraz sposób sfinansowania spłaty długu,

- kwoty wydatków bieżących i majątkowych wynikających z limitów wydatków na planowane i realizowane przedsięwzięcia.

Dodatkowo, jako załącznik do uchwały, zamieszcza się wykaz przedsięwzięć (programów, projektów, zadań) związanych przede wszystkim z programami finansowanymi środkami z UE i umowami o partnerstwie publiczno-prywatnym. Ponadto prognozę sporządza się na okres roku budżetowego oraz co najmniej trzech kolejnych lat budżetowych, przy czym prognozę kwoty długu sporządza się na okres, na który zaciąnnięto oraz planuje się zaciagnąć zobowiąania.

Duże znaczenie praktyczne miało wprowadzenie w życie rozporządzenia Ministra Finansów z 10 stycznia 2013 r. w sprawie wieloletniej prognozy finansowej jednostek samorządu terytorialnego ${ }^{10}$, w którym określono wzór WPF oraz sposób i terminy przekazywania jej przez jednostkę do regionalnych izb obrachunkowych (RIO) oraz przez RIO do Ministerstwa Finansów. Oprócz tego, że rozporządzenie to pozwala ministerstwu lepiej kontrolować samorząd, głównie pod kątem zadłużenia, to publikowanie przez ministerstwo zbiorczych zestawień WPF posiada swój walor poznawczy dla osób zajmujacych się finansami samorządowymi i umożliwia prowadzenie badań. Dzięki temu w niniejszym artykule autorzy, wykorzystując zestawienia publikowane przez ministerstwo ${ }^{11}$, postanowili zbadać tendencje w zakresie sposobów planowania zadłużenia przez jednostki i jego spłaty. W kolejnych punktach badaniu zostaną poddane odpowiednio planowana wielkość i struktura zadłużenia jednostek samorządu terytorialnego w Polsce oraz jego obsługa. Badanie zostanie przeprowadzone w podziale na poszczególne szczeble samorządu terytorialnego dla okresu od 2010 r., przy czym dane za lata 2010-2012 stanowią wartości wykonane poszczególnych kategorii finansowych (według sprawozdań z wykonania budżetu) ${ }^{12}$, wartości od 2013 r. (włącznie) są zaś wielkościami planowanymi (prognozowanymi), według zapisu w uchwałach o wieloletniej prognozie finansowej sporządzonych przez jednostki na rok 2013 i kolejne lata.

\footnotetext{
10 Dz. U. 2013, Nr 0, poz. 86.

11 Wieloletnia prognoza finansowa jednostek samorzqdu terytorialnego - rok 2013, Ministerstwo Finansów, Warszawa 2013, www.mf.gov.pl (aktualizacja danych na: 19 września 2013 r.).

12 Fakt ten został odnotowany na prezentowanych w dalszej części wykresach poprzez umieszczenie przy liczbie określającej rok litery „W”.
} 


\section{PROGNOZOWANE ZADLUŻENIE JEDNOSTEK SAMORZĄDU TERYTORIALNEGO W POLSCE}

Wartość nominalną zadłużenia jednostek samorządu terytorialnego w podziale na poszczególne rodzaje jednostek przedstawiono na wykresie 1 . Na wstępie należy zauważyć, że ostatni okres przed sporządzeniem prognozy (do 2012 r.) to lata stałego, dynamicznego wzrostu długu samorządowego, postępującego $\mathrm{w}$ zasadzie od momentu reaktywacji samorządu terytorialnego w Polsce na początku transformacji systemowej. Kulminacja wartości długu przypada na 2013 r., co jest zrozumiałe, gdyż jednostki planują najczęściej zaciagnięcie zobowiązań przede wszystkim na najbliższy rok budżetowy (tutaj2013), a sporadycznie na kolejne lata. Po tym roku następuje sukcesywny spadek wielkości planowanego zadłużenia, w nielicznych przypadkach trwający aż do 2048 r. Nie oznacza to, że jednostki po 2013 r. nie będą zwiększały swojego długu. Jak można się spodziewać, w kolejnych formułowanych WPF na lata $2014+$ znajdą się nowe zobowiązania, co wynika chociażby z faktu otwarcia nowej perspektywy w finansowaniu projektów ze środków Unii Europejskiej.

Wykres 1

Prognozowana wartość nominalna zadłużenia jednostek samorządu terytorialnego w Polsce (w mld PLN)

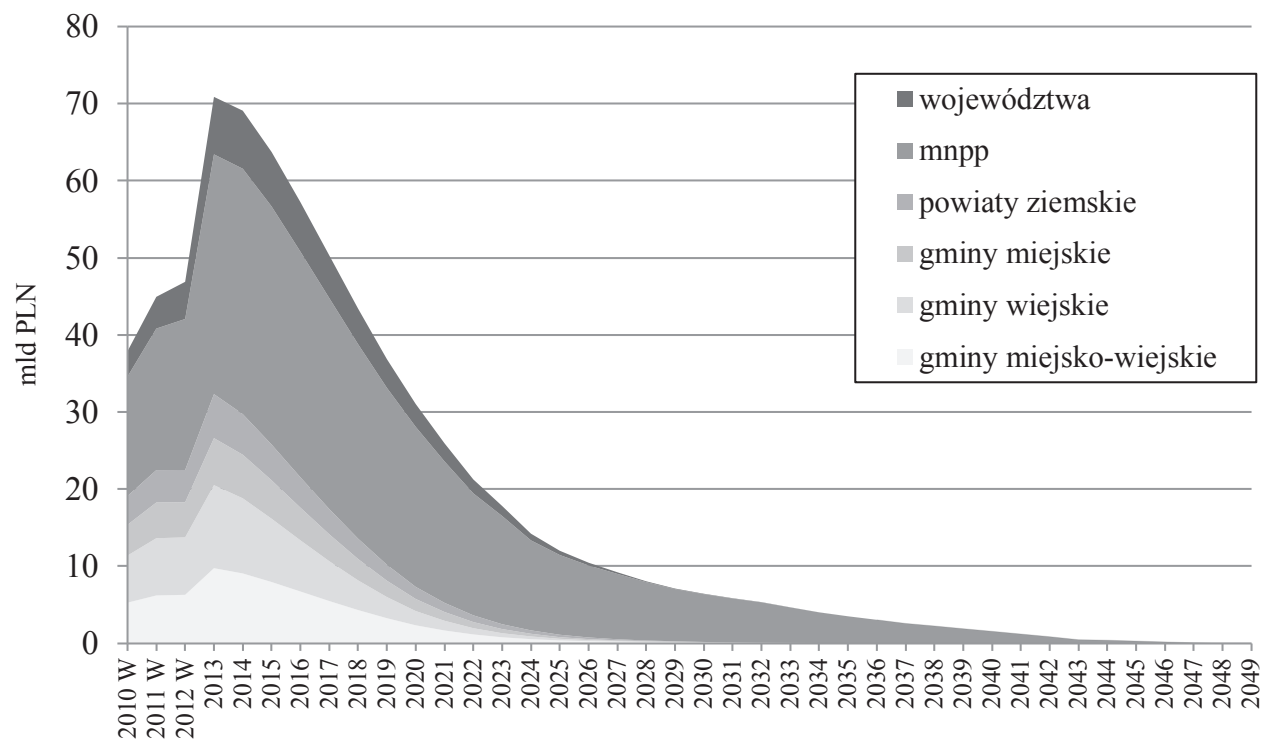

Źródło: opracowanie własne na podstawie danych Ministerstwa Finansów. 
Dominującą cześć zadłużenia samorządowego w Polsce stanowią zobowiązania miast na prawach powiatu (mnpp) - zarówno pod względem wartości nominalnej, jak również długości terminu, na jaki zostały one zaciagnięte. Fakt ten wynika z kilku czynników: przede wszystkim z tego, że są to jednostki najsilniejsze finansowo, mające zdolność do zaciąnięcia tak dużych zobowiąań i których mieszkańcy również najczęściej mają duże oczekiwania - głównie inwestycyjne - wobec władz lokalnych.

Prezentację wartości długu należy uzupełnić o wskazanie, ilu jednostek on dotyczy, dlatego też na wykresie 2 zaprezentowano odsetek jednostek planujących swoje zadłużenie w poszczególnych latach prognozy. Jak można zauważyć, przeciętnie połowa podmiotów przyjmuje nie dłuższy niż 10-letni plan spłaty obecnego i planowanego w najbliższej przyszłości zadłużenia (mniej więcej do 2022 r.). Inaczej jest w przypadku województw i miast na prawach powiatu, których większość pozostanie zadłużona przez okres dłuższy niż 13 lat, a co piąte miasto na prawach powiatu przyjęło przynajmniej 20-letni harmonogram spłat długu.

Wykres 2

Odsetek zadłużonych jednostek samorządu terytorialnego w Polsce według WPF na lata $2013+$

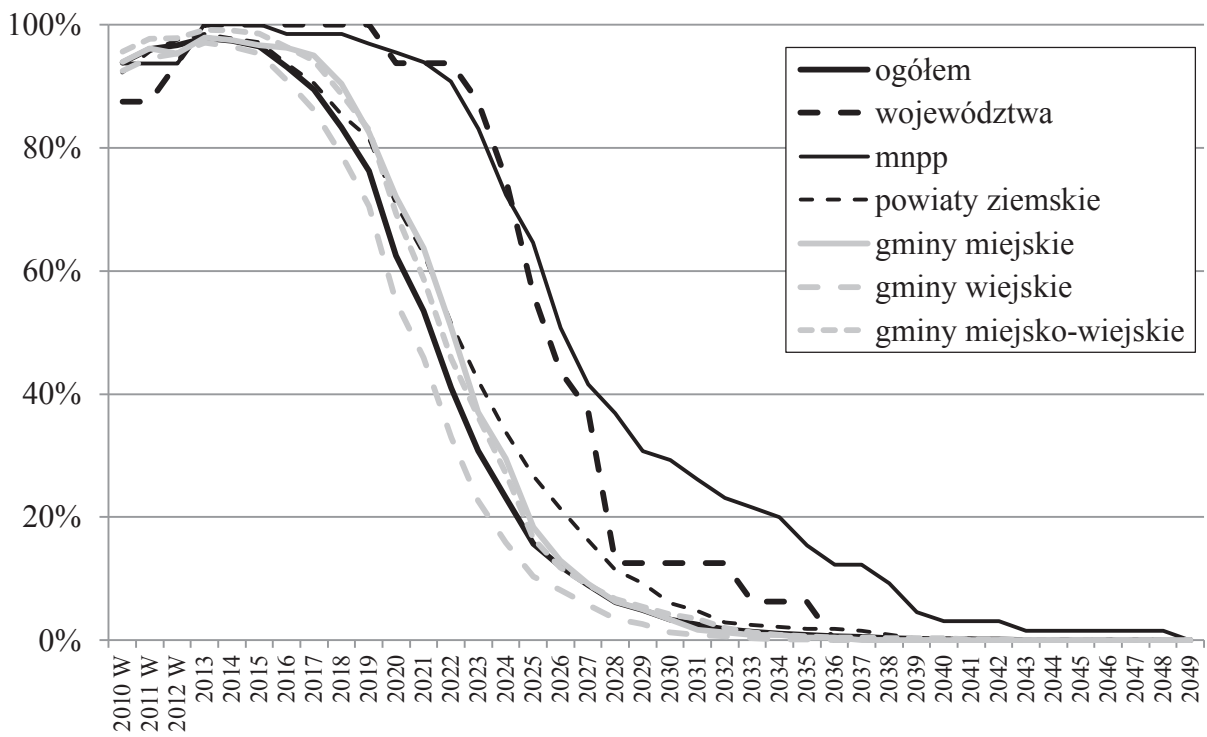

Źródło: opracowanie własne na podstawie danych Ministerstwa Finansów.

Kolejną charakterystyką pozwalająca ocenić obciążenie jednostek samorządu terytorialnego długiem jest porównanie wartości ich zobowiązań z wysokością uzyskiwanych dochodów. Porównanie to ma duże znaczenie, ponieważ badane grupy jednostek są bardzo zróżnicowane, zarówno pod względem 
liczebności, jak i potencjału finansowego. Zatem ocena obciążenia jednostek długiem powinna zostać dokonana w ujęciu względnym, w tym celu też na wykresie 3 przedstawiono średnią wartość relacji długu do dochodów ogółem badanych jednostek. Należy zaznaczyć jednak, że średnie wartości wskaźników wyznaczono dla jednostek, które uchwaliły na dany rok WPF, ergo takich, które według planu mają pozostawać w danym roku zadłużone lub zakończą spłatę długu. Dlatego w badaniu wartość średnią analizowanej relacji warto mieć na uwadze charakterystyki przedstawione na wykresie 2. W rzeczywistości, gdyby uwzględnić potencjalne dochody jednostek, które planowały wcześniej spłacić zadłużenie, przez to nie dokonywały prognoz dochodów na okresy tak odległe w przód, „prawy ogon” wykresu stałby się „cieńszy”. Ponadto uśrednienia dokonano w sposób arytmetyczny - nie ważono wartości wskaźników wielkością prognozowanych dochodów czy też długu.

Wykres 3

Średnia wartość relacji prognozowanej wartości długu do dochodów ogółem jednostek zadłużonych

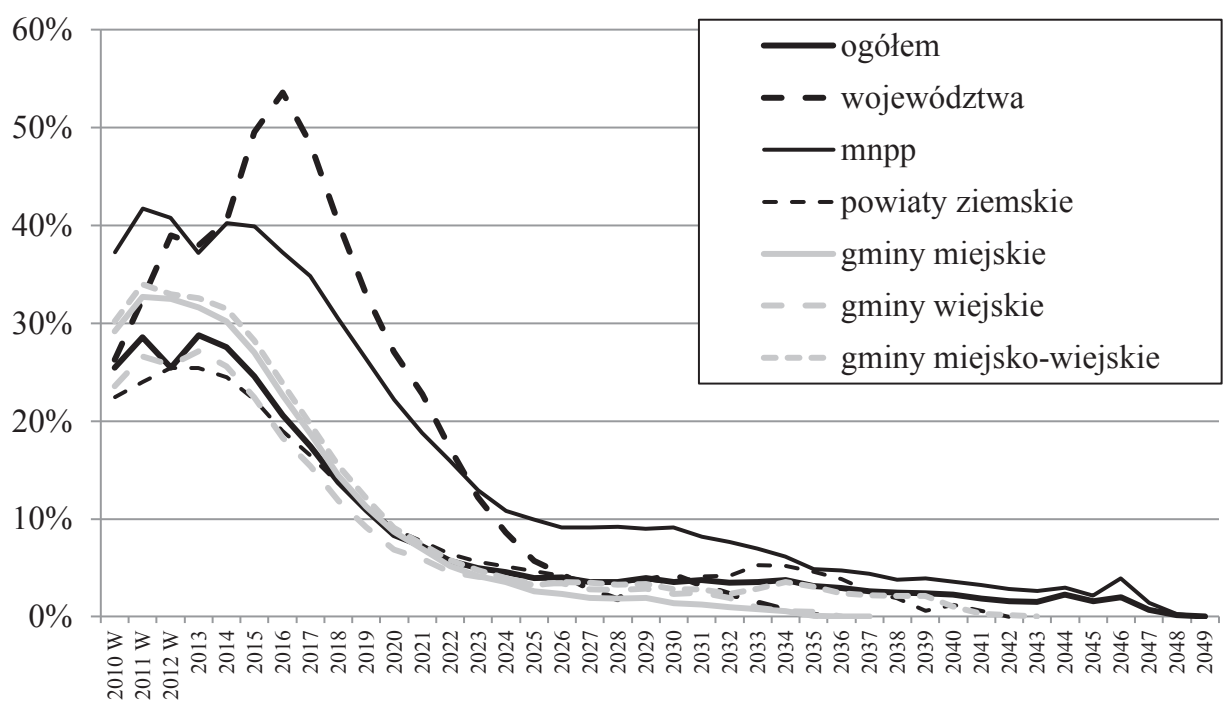

Źródło: opracowanie własne na podstawie danych Ministerstwa Finansów.

Wartości wskaźnika obrazującego obciążenie dochodów jednostek ich długiem pozwalają stwierdzić, że również w ujęciu względnym najbardziej zadłużone będą miasta na prawach powiatu oraz województwa. Interesujące jest jednak to, że w pierwszych 10 latach prognozy to województwa wykazują relatywnie wyższe (w stosunku do swoich dochodów) zadłużenie niż miasta.

Warto rozpatrywać wykres 3 także w kategoriach przepisów limitujących dług samorządowy do końca 2013 r., zapisanych w ustawie o finansach pub- 
licznych z 2005 r. (art. 170), a zastapionych od 2014 r. indywidualnym wskaźnikiem zadłużenia, zdefiniowanym w art. 243 ustawy o finansach publicznych z 2009 r. Według wygasających ograniczeń, wartość wskaźników prezentowanych na wykresie 3 nie mogła być w przypadku poszczególnych jednostek wyższa od $60 \%$ i przeciętnie w okresie prognozy limit ten nie zostałby naruszony. Fakt ten, choć pozytywny, nie świadczy o tym, że wysokość planowanego długu jest na bezpiecznym poziomie. Dla właściwej oceny skali zadłużenia ważniejsza wydaje się zdolność jednostek do spłaty długu, zależna przede wszystkim od tego, jaką część dochodów można przeznaczyć na spłatę zobowiązań, stąd istotniejsze wydaje się przyrównanie zadłużenia do nadwyżki operacyjnej ${ }^{13}$ (dochodów bieżących pomniejszonych o wydatki bieżące).

Ze względu na to, że wartości relacji długu do dochodów ogółem kształtowały się w sposób bardzo zróżnicowany w badanych grupach, w tabeli 1 postanowiono przedstawić również najważniejsze charakterystyki rozkładu badanego wskaźnika i zaprezentowano dla poszczególnych grup, oprócz średniej, również odchylenie standardowe i współczynnik zmienności (stosunek odchylenia standardowego do średniej) oraz wartości minimalną i maksymalną. Z uwagi na ograniczoną objętość opracowania zdecydowano się przedstawić uśrednione wartości charakterystyk tylko w trzech podokresach:

- lata 2010-2012: okres poprzedzający sporządzenie prognozy (wartości rzeczywiste, wykonane),

- lata 2013-2016: okres, na który w myśl przepisów każda jednostka (zadłużona lub nie) miała obowiązek sporządzenia prognozy,

- lata 2013-2022: okres pierwszych 10 lat prognozy, w którym około połowy wszystkich jednostek planowało spłatę posiadanego zadłużenia ${ }^{14}$.

Analizując wartości średniej relacji długu do dochodów ogółem, warto zauważyć, że przeciętnie jest ona niższa w okresie prognozy niż w latach ją poprzedzających. Wyjątek stanowią województwa, których zadłużenie w okresie obowiązkowej prognozy (2013-2017) jest przeciętnie o połowę wyższe niż w ciągu trzech lat poprzedzających prognozę.

Ocena wartości miar zróżnicowania badanej relacji pozwala stwierdzić generalnie, że w ujęciu bezwzględnym (odchylenie standardowe) zróżnicowanie $\mathrm{w}$ okresie prognozy pozostało na podobnym poziomie, jak w okresie poprzedzającym, a nawet nieznacznie się zmniejszyło - wyjątek stanowią powiaty ziemskie. Jednakże badając miary względne (współczynnik zmienności), trzeba zauważyć, że w przypadku 10 lat WPF wskaźnik obciążenia długiem charakteryzował się najwyższą zmiennością - możliwe wartości wskaźnika mogą odchylać się średnio nawet o $94,12 \%$ od jego poziomu przeciętnego, gdy

${ }^{13}$ Wskaźnik długu do dochodów jest wykorzystywany jako narzędzie do sporządzania rankingów zadłużenia - przykładowo ranking publikowany na łamach „Wspólnoty”, autorstwa P. Swianiewicza i J. Łukomskiej, pokazujący według rodzaju jednostki najbardziej i najmniej zadłużone. Sami autorzy wskazuja jednak, że miara ta niekoniecznie jest najlepszym sposobem pomiaru obciążenia jednostki długiem, za to większe znaczenie ma przyrównanie długu do nadwyżki operacyjnej. Por. P. Swianiewicz, J. Łukomska, op. cit.

${ }^{14}$ Nie brano pod uwagę okresu po roku 2022, ponieważ wyniki mogłyby być niemiarodajne, przede wszystkim z uwagi na malejącą liczebność jednostek, które planowały w tym czasie pozostać zadłużone. 
Tabela 1

Zróżnicowanie obciążenia długiem poszczególnych grup jednostek samorządu terytorialnego w Polsce

\begin{tabular}{|c|c|c|c|c|}
\hline $\begin{array}{c}\text { Charakterystyki } \\
\text { rozkładu }\end{array}$ & Rodzaj jst & $\begin{array}{c}3 \text { lata przed } \\
\text { WPF } \\
(2010-2012)\end{array}$ & \begin{tabular}{|c|}
4 lata \\
(obowiązkowe) \\
WPF \\
$(2013-2016)$
\end{tabular} & $\begin{array}{l}10 \text { lat WPF } \\
(2013-2022)\end{array}$ \\
\hline \multirow[t]{7}{*}{ średnia } & ogólem & $26,51 \%$ & $25,37 \%$ & $16,48 \%$ \\
\hline & województwa & $32,58 \%$ & $45,40 \%$ & $37,01 \%$ \\
\hline & mnpp & $39,92 \%$ & $38,63 \%$ & $30,31 \%$ \\
\hline & powiaty ziemskie & $23,93 \%$ & $22,75 \%$ & $15,55 \%$ \\
\hline & gminy miejskie & $31,46 \%$ & $27,84 \%$ & $17,65 \%$ \\
\hline & gminy wiejskie & $25,30 \%$ & $23,36 \%$ & $14,72 \%$ \\
\hline & gminy miejsko-wiejskie & $32,37 \%$ & $29,03 \%$ & $18,55 \%$ \\
\hline \multirow{7}{*}{$\begin{array}{l}\text { odchylenie } \\
\text { standardowe }\end{array}$} & ogólem & 16,52 p.p. & 15,13 p.p. & 12,79 p.p. \\
\hline & województwa & 19,63 p.p. & 14,34 p.p. & 14,27 p.p. \\
\hline & mnpp & 16,07 p.p. & 15,52 p.p. & 17,02 p.p. \\
\hline & powiaty ziemskie & 14,97 p.p. & 18,75 p.p. & 16,66 p.p. \\
\hline & gminy miejskie & 16,21 p.p. & 13,07 p.p. & 10,67 p.p. \\
\hline & gminy wiejskie & 16,46 p.p. & 14,14 p.p. & 11,16 p.p. \\
\hline & gminy miejsko-wiejskie & 15,44 p.p. & 14,14 p.p. & 11,88 p.p. \\
\hline \multirow{7}{*}{$\begin{array}{l}\text { współczynnik } \\
\text { zmienności }\end{array}$} & ogólem & $62,45 \%$ & $60,69 \%$ & $94,12 \%$ \\
\hline & województwa & $61,73 \%$ & $31,47 \%$ & $41,69 \%$ \\
\hline & mnpp & $40,29 \%$ & $40,22 \%$ & $62,87 \%$ \\
\hline & powiaty ziemskie & $62,69 \%$ & $83,64 \%$ & $124,75 \%$ \\
\hline & gminy miejskie & $51,62 \%$ & $47,62 \%$ & $74,80 \%$ \\
\hline & gminy wiejskie & $65,16 \%$ & $61,72 \%$ & $92,27 \%$ \\
\hline & gminy miejsko-wiejskie & $47,82 \%$ & $49,52 \%$ & $79,06 \%$ \\
\hline \multirow{7}{*}{$\begin{array}{l}\text { wartość } \\
\text { maksymalna }\end{array}$} & ogółem & $94,09 \%$ & $237,55 \%$ & $218,65 \%$ \\
\hline & województwa & $58,40 \%$ & $66,96 \%$ & $61,14 \%$ \\
\hline & mnpp & $64,23 \%$ & $87,87 \%$ & $96,46 \%$ \\
\hline & powiaty ziemskie & $63,35 \%$ & $237,55 \%$ & $218,65 \%$ \\
\hline & gminy miejskie & $85,70 \%$ & $71,40 \%$ & $61,64 \%$ \\
\hline & gminy wiejskie & $94,09 \%$ & $105,34 \%$ & $95,65 \%$ \\
\hline & gminy miejsko-wiejskie & $85,55 \%$ & $96,74 \%$ & $80,49 \%$ \\
\hline \multirow{7}{*}{$\begin{array}{l}\text { wartość } \\
\text { minimalna }\end{array}$} & ogółem & $0,00 \%$ & $0,00 \%$ & $0,00 \%$ \\
\hline & województwa & $0,00 \%$ & $11,89 \%$ & $7,79 \%$ \\
\hline & mnpp & $0,00 \%$ & $0,08 \%$ & $0,42 \%$ \\
\hline & powiaty ziemskie & $0,00 \%$ & $0,00 \%$ & $0,00 \%$ \\
\hline & gminy miejskie & $0,00 \%$ & $0,00 \%$ & $0,00 \%$ \\
\hline & gminy wiejskie & $0,00 \%$ & $0,00 \%$ & $0,00 \%$ \\
\hline & gminy miejsko-wiejskie & $0,00 \%$ & $0,00 \%$ & $0,00 \%$ \\
\hline
\end{tabular}

Źródło: obliczenia własne na podstawie danych Ministerstwa Finansów. 
np. w pierwszych 4 latach to odchylenie przeciętnie kształtowało się na poziomie $60,69 \%$. Wzrost wskaźnika zmienności wynika oczywiście ze spadku wartości średniej przy dosyć zbliżonym odchyleniu standardowym. Konkludując, tendencje w zakresie zróżnicowania wśród jednostek prognozowanej wartości relacji zadłużenia do dochodów ogółem należy ocenić pozytywnie - zróżnicowanie wartości planowanych nie odbiega od stanu z okresu przed dokonaniem prognozy, a przeciętnie w kategoriach bezwzględnych ulega nawet obniżeniu.

Ważnych informacji dostarcza również badanie wartości maksymalnych i minimalnych, pozwalające określić rozstęp wartości charakteryzowanej relacji. W większości rodzajów jednostek można znaleźć takie, które długu w okresie prognozy nie planują posiadać, z wyjątkiem województw i miast na prawach powiatu, przy czym $\mathrm{w}$ tych pierwszych zadłużenie minimalne w okresie obowiąkowej prognozy ma przekroczyć 10\% dochodów. Z kolei w przypadku wartości maksymalnej należy odnotować fakt, iż w większości jednostek będzie ona przeciętnie wyższa $\mathrm{w}$ okresie prognozy niż wcześniej, a wyjątek stanowia tu jedynie gminy miejskie. Co ważne, oznacza to, że gdyby po $2013 \mathrm{r}$. utrzymany został limit relacji długu do dochodów ogółem na poziomie $60 \%$, można byłoby znaleźć jednostki, które miałyby poważne problemy z utrzymaniem dyscypliny finansów publicznych.

\section{PROGNOZOWANA OBSŁUGA ZADŁUŻENIA JEDNOSTEK SAMORZĄDU TERYTORIALNEGO W POLSCE}

Finansowanie zwrotne zadań samorządowych, skutkujące wzrostem długu samorządowego, pociaga za sobą szereg strumieni finansowych, związanych zarówno z przepływem kapitału, jak i jego kosztami. Pozyskanie przez jednostkę kapitałów znajduje swoje odzwierciedlenie w wielkości jej przychodów, jego spłata zaś stanowi jej rozchody. Z kolei koszty długu - przyjmujace formę odsetek i dyskonta - zaliczane sa do wydatków bieżących jednostki i kształtuja przez to poziom jej salda operacyjnego. Aby zbadać te kategorie finansowe, w pierwszej kolejności zostaną zaprezentowane prognozowane przez jednostki wielkości przychodów i rozchodów związanych z zaciaganiem i spłatą zobowiązań $^{15}$, a następnie prognozowana obsługa długu, tj. spłata długu w połączeniu z kosztami zobowiąań.

Porównanie wielkość przychodów i rozchodów jednostek planowanych w związku z tworzeniem długu i jego spłata przedstawiono na wykresie 4 . W okresie poprzedzającym prognozę zaobserwować można wysokie wartości przychodów przy relatywnie niższych wartościach rozchodów, czego skutkiem był gwałtowny przyrost wolumenu zadłużenia w tym okresie. W kolejnych latach jednostki zaplanowały zaciaganie nowych zobowiązań finansujących deficyty przede wszystkim w pierwszych latach prognozy, po 2016 r. zaś mają one praktycznie charakter śladowy.

15 Badaniu nie poddawano przychodów i rozchodów innych niż te związane z tworzeniem ich długu, np. tych związanych ze zobowiązaniami innych podmiotów wobec jednostek samorządu terytorialnego. 


\section{Wykres 4}

Prognozowane przychody i rozchody samorządowe związane z tworzeniem długu i jego spłata

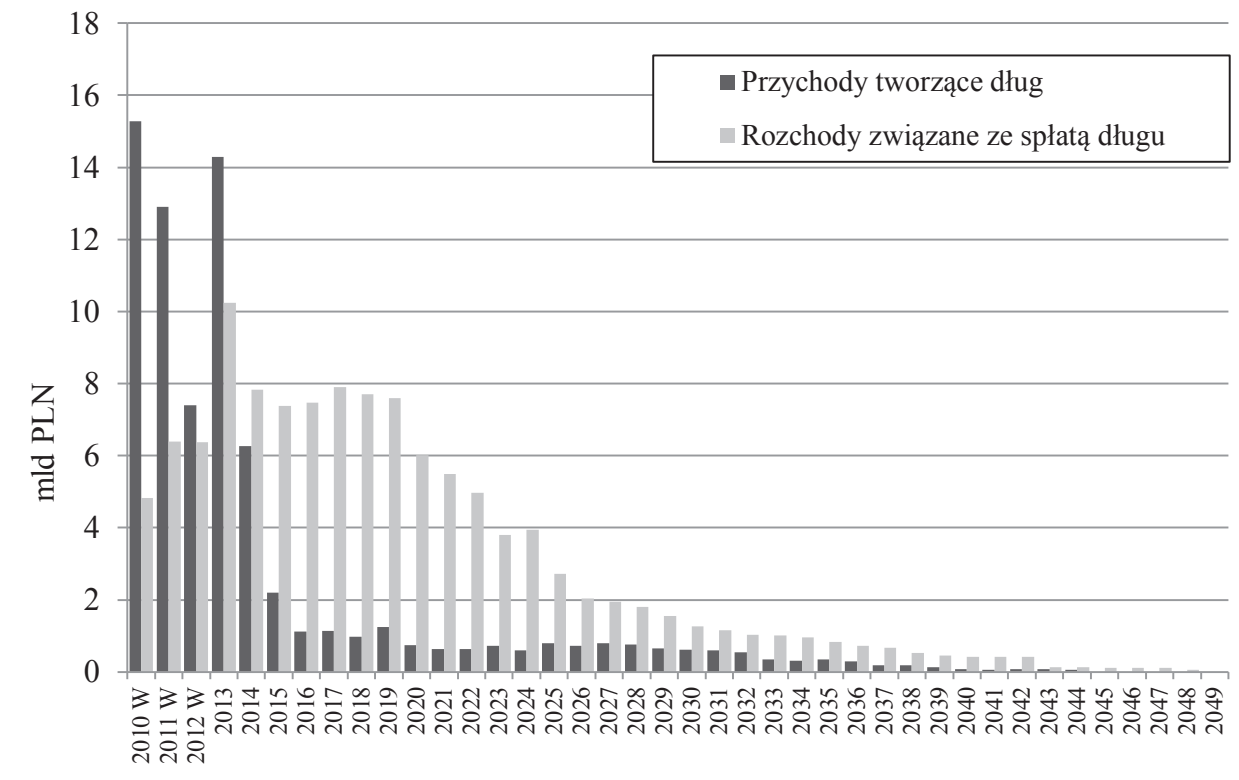

Źródło: opracowanie własne na podstawie danych Ministerstwa Finansów.

Kluczowy z punktu widzenia analizy przychodów i rozchodów jest rok 2013. W roku tym zaplanowane zostało zaciagnięcie nowych zobowiązań na kwotę przeszło 14 mld zł, czemu towarzyszyła jednak równie olbrzymia spłata zobowiązań w kwocie ponad 10 mld zł. Jak się wydaje, miało to duży związek z restrukturyzacją zadłużenia wielu jednostek, dokonywaną w celu sprostania indywidualnym limitom długu obowiązującym od 2014 r. Aby spełnić nowe przepisy, niektóre jednostki musiały przyspieszyć spłatę zadłużenia, dzięki której obniżeniu ulegała kwota środków wydatkowanych w przyszłości. Dzięki takiemu zabiegowi możliwe stało się wypełnienie przepisów art. 243 ustawy o finansach publicznych z 2009 r. ${ }^{16} \mathrm{~W}$ kolejnych latach, do 2020 r., planowane rozchody kształtują się na stabilnym, wysokim poziomie 7-8 mld zł, co skutkować będzie znacznym obniżeniem długu w tym okresie: z ponad 70 do 25 mld zł. Po 2020 r. obserwować można stopniowe zmniejszanie się kwot planowanych rozchodów, co przełoży się na wolniejsze tempo spadku wolumenu długu.

\footnotetext{
${ }^{16}$ Przykład restrukturyzacji długu samorządowego wywołanej m.in. nowymi limitami zadłużenia na przykładzie powiatu można znaleźć w: A. Zdziebło, Zarzqdzanie dtugiem w jednostce samorzadu terytorialnego na przyktadzie Powiatu Chodzieskiego w latach 2010-2013, w: T. Gabrusewicz, K. Marchewka-Bartkowiak, M. Wiśniewski (red.), Rachunkowość, finanse, audyt i kontrola. Studium przypadków podmiotów sektora publicznego i prywatnego, CeDeWu, Warszawa 2013, s. 209-224.
} 
Rozplanowanie w czasie przychodów i rozchodów związanych ze zobowiazaniami jednostek samorządu terytorialnego jest różne dla poszczególnych szczebli samorządu terytorialnego, dlatego osobno przedstawiono strukturę podmiotowa tych kategorii ekonomicznych (wykresy 5 i 6).

W obydwu sytuacjach dominują miasta na prawach powiatu, gdyż ich dług jest relatywnie największy, ale obserwowalne są także inne tendencje w zakresie planowania nowych zobowiązań i ich spłaty w przypadku innych jednostek. W okresie prognozy jednostkami, które decydują się zaciagnąć dodatkowy dług, poza liderami, tj. miastami na prawach powiatu, są województwa, $\mathrm{w}$ mniejszym stopniu gminy, a w najmniejszym powiaty ziemskie. Zaciaganie nowych zobowiązań przez miasta na prawach powiatu nie jest zaskakujące, chociaż ich dług jest i tak już największy na tle innych jednostek. Fakt ten można wyjaśnić przede wszystkim oczekiwaniami (głównie inwestycyjnymi), które są wobec tych jednostek relatywnie największe. Najmniejsza zaplanowana skala korzystania ze zwrotnych przychodów w przypadku powiatów ziemskich wynika z kolei z niskiej zdolności tych jednostek do zaciagania zobowiązań, w szczególności w świetle nowych limitów zadłużenia, o których już wspominano.

Z kolei badanie prognoz spłaty zadłużenia (rozchodów) wskazuje na to, że ponownie to miasta na prawach powiatu wiodą prym pod względem długości przesunięcia spłaty swoich zobowiązań w czasie. W relatywnie krótkim czasie planują spłacić swój dług województwa, a w następnej kolejności gminy, w tym gminy wiejskie.

\section{Wykres 5}

Struktura podmiotowa prognozowanych przychodów samorządowych związanych z zaciaganiem długu

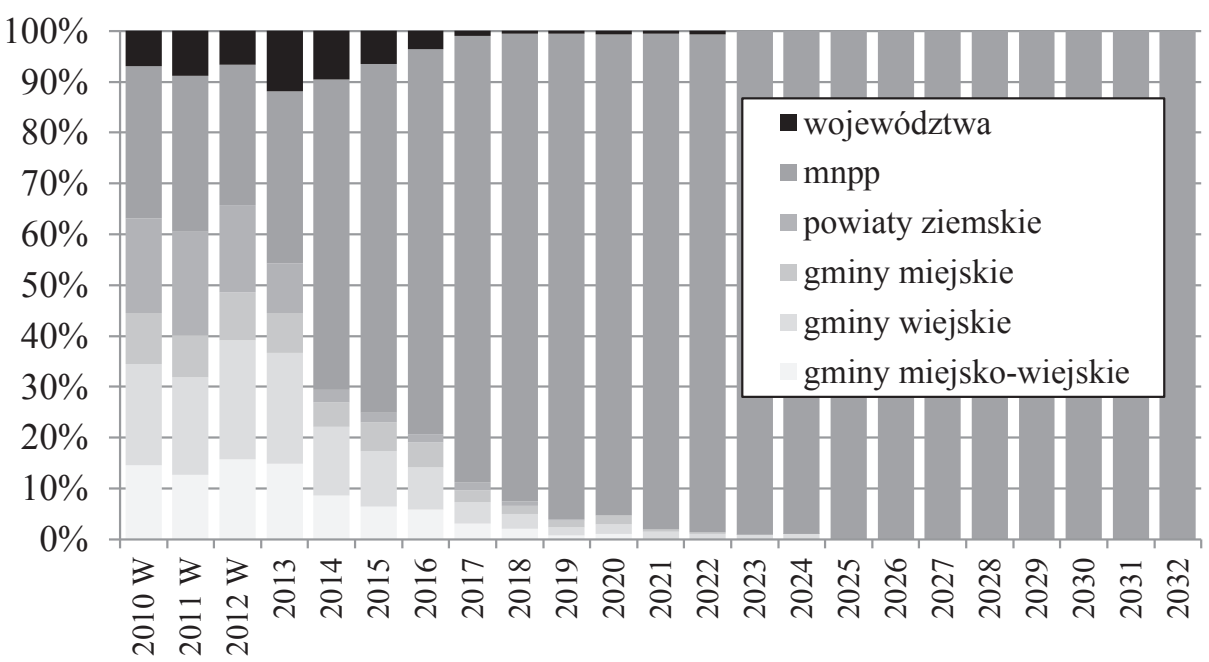

Źródło: opracowanie własne na podstawie danych Ministerstwa Finansów. 
Wykres 6

Struktura podmiotowa prognozowanych rozchodów samorządowych związanych ze spłatą długu

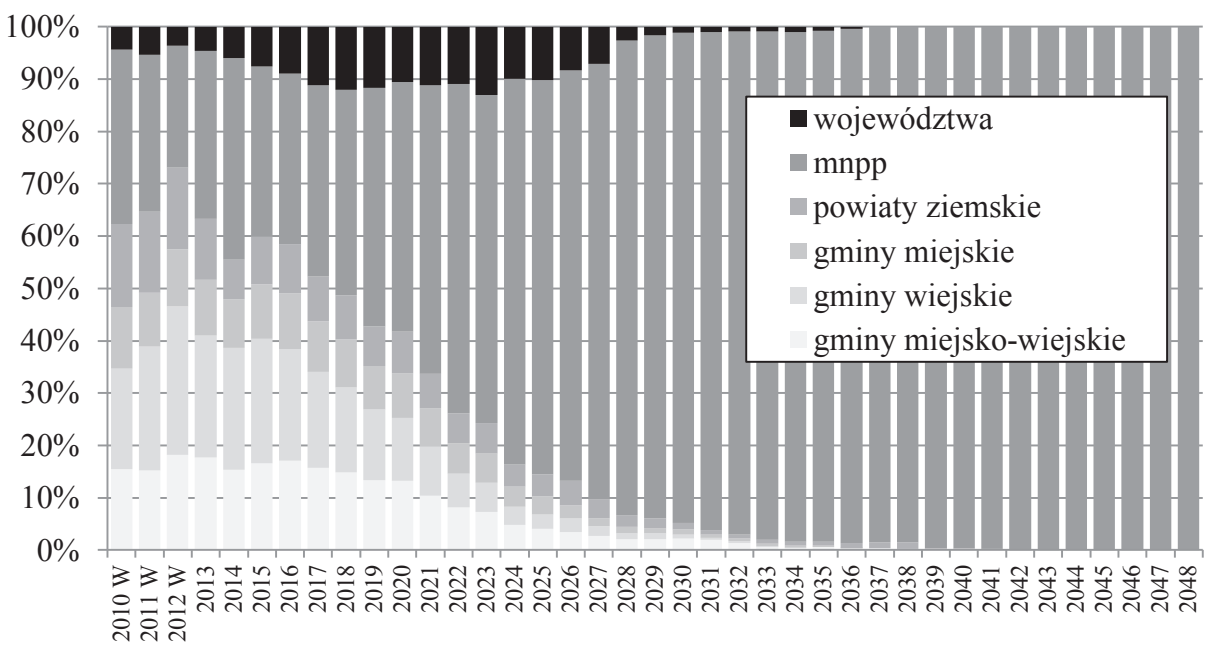

Źródło: opracowanie własne na podstawie danych Ministerstwa Finansów.

W następnej kolejności zbadano obciążenia przyszłych budżetów samorządowych związane z obsługą długu. Na wykresie 7 przedstawiono w sposób skumulowany prognozowane wartości spłat rat kapitału (klasyfikowane jako rozchody jednostek) oraz odsetki (zaliczane do wydatków bieżących jednostek) lewa oś. Dla czytelniejszego przedstawienia proporcji pomiędzy elementami kwot związanych z obsługą długu zaprezentowano również udział wydatków bieżących (,odsetki”) w sumie środków wydatkowanych w związku z obsługa zadłużenia (,odsetki + rozchody") - prawa oś.

W okresie przed sporządzeniem prognoz (lata 2010-2012) odnotowuje się wzrost wartości środków wydatkowanych na obsługę zadłużenia - kulminacyjnym rokiem, jak już wskazano wcześniej, jest rok 2013, w którym badane kwoty były najwyższe. W kolejnych latach planowana jest sukcesywna spłata długu wraz ze stosownymi odsetkami. Wysokie kwoty planowanych odsetek i rozchodów w początkowych latach wynikają oczywiście z konieczności obsługi długu, jaki jednostki zaciąnnęły oraz planują zaciagnąć, i kształtują się one analogicznie do wielkości zobowiązań (porównaj wykres 1). Przyczyną najwyższej wartości odsetek i rozchodów w 2013 r. wydaje się konieczność restrukturyzacji zadłużenia $\mathrm{w}$ wielu jednostkach, wymuszona koniecznością spełnienia od 2014 r. wymogów stawianych pod postacią nowego, indywidualnego wskaźnika zadłużenia.

Warto podkreślić, że w latach objętych prognozą udział odsetek (wydatków) w sumie środków publicznych planowanych przez samorządy na obsługę długu (wykres 7, prawa oś) jest dość stabilny i kształtuje się na poziomie około jednej czwartej. Jednakże i w tym przypadku można odnaleźć zróżnicowanie pomiędzy 
Wykres 7

Prognozowana obsługa długu samorządowego w Polsce

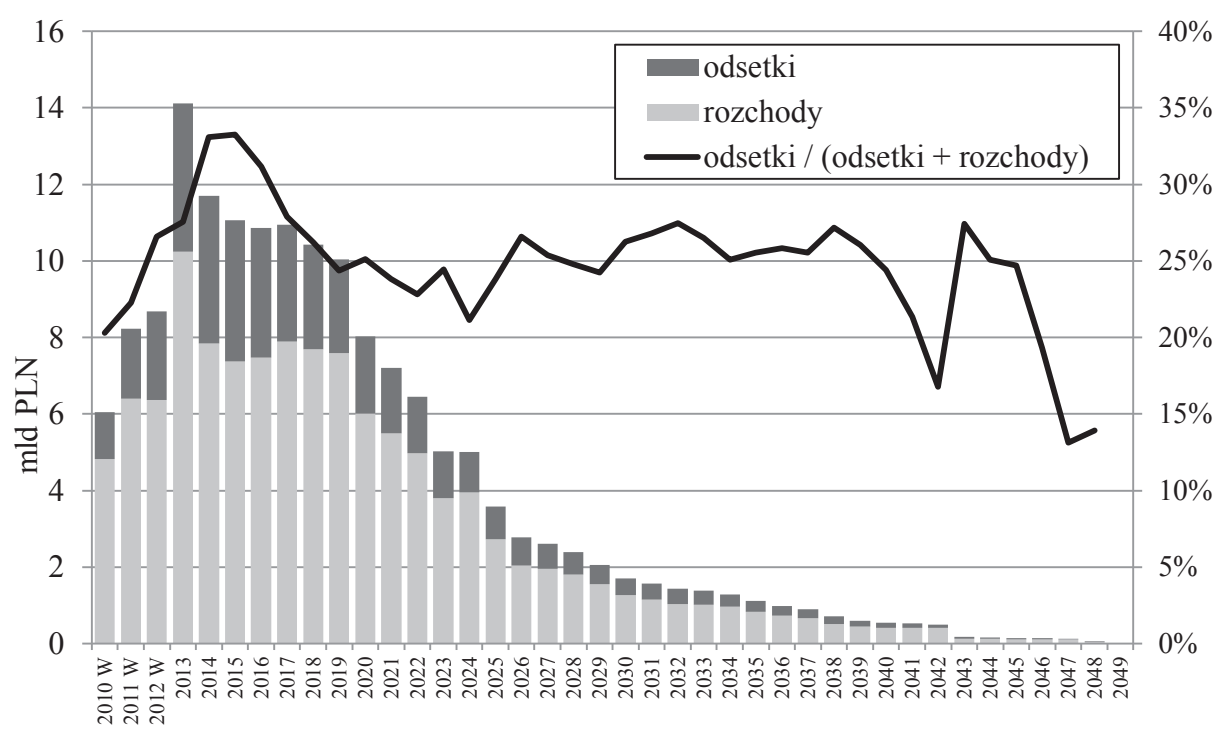

Źródło: opracowanie własne na podstawie danych Ministerstwa Finansów.

szczeblami samorządu. W celu przybliżenia tych różnic w tabeli 2 przestawiono uśrednione wartości badanej relacji dla okresu sprzed prognozy oraz dla 4 i 10 pierwszych lat prognozy - dla poszczególnych rodzajów jednostek samorządu terytorialnego.

Należy zauważyć, że we wszystkich przypadkach najwyższy udział odsetek w puli środków wydatkowanych na obsługę długu występuje w okresie pierwszych 4 lat obowiązkowej dla wszystkich jednostek prognozy. Wiąże się to z wysoką wartością długu, którego spłatę rozłożono zwykle na mniej niż 10 lat. Ponieważ województwa i miasta na prawach powiatu sa jednostkami, które przyjęły znacząco dłuższy plan spłaty kapitału, udział odsetek w obsłudze zadłużenia jest $\mathrm{w}$ tym czteroletnim podokresie najwyższy: wynosi aż $41,5 \%$ dla województw i prawie $40 \%$ - miast. Z długoterminowym planem spłaty zadłużenia związany jest również fakt, że dla kolejnego podokresu (10 lat WPF) najwyższy udział odsetek otrzymano dla miast na prawach powiatu - jak wcześniej wskazano - jedna piąta tych jednostek planuje spłatę zobowiązań jeszcze po 2034 r. Odwrotnie jest w przypadku gmin, w szczególności wiejskich, w których wysokość analizowanego wskaźnika w badanym okresie prognozy pozostaje przeważnie w przedziale 15-20\%. Prawidłowość tę należy tłumaczyć inną polityką zarządzania długiem, w szczególności mniejszą skłonnością do zaciagania zobowiązań o bardzo długim terminie wymagalności. 
Tabela 2

Udział odsetek w prognozowanej kwocie środków publicznych przeznaczonych na obsługę długu samorządowego według rodzaju jednostek

\begin{tabular}{|l|l|c|c|c|}
\hline \multicolumn{2}{|c|}{ Średnia w okresie } & $\begin{array}{c}\text { 3 lata } \\
\text { przed WPF } \\
(\mathbf{2 0 1 0 - 2 0 1 2})\end{array}$ & $\begin{array}{c}\text { 4 lata } \\
\text { (obowiązkowe) }\end{array}$ & $\begin{array}{c}\text { WPF (2013-2016) } \\
\text { (2013-2022) }\end{array}$ \\
\hline $\begin{array}{l}\text { Rodzaj } \\
\text { jst }\end{array}$ & ogólem & $23,05 \%$ & $31,26 \%$ & $27,53 \%$ \\
\cline { 2 - 5 } & województwa & $\mathbf{3 4 , 8 6 \%}$ & $\mathbf{4 1 , 4 9 \%}$ & $29,65 \%$ \\
\cline { 2 - 5 } & mnpp & $30,14 \%$ & $\mathbf{3 9 , 8 9 \%}$ & $\mathbf{3 4 , 6 5 \%}$ \\
\cline { 2 - 5 } & powiaty ziemskie & $25,29 \%$ & $27,33 \%$ & $22,81 \%$ \\
\cline { 2 - 5 } & gminy miejskie & $21,24 \%$ & $26,71 \%$ & $22,13 \%$ \\
\cline { 2 - 5 } & gminy wiejskie & $15,34 \%$ & $19,58 \%$ & $17,50 \%$ \\
\cline { 2 - 5 } & $\begin{array}{l}\text { gminy miejsko- } \\
\text {-wiejskie }\end{array}$ & $19,11 \%$ & $24,80 \%$ & $20,73 \%$ \\
\hline
\end{tabular}

Źródło: opracowanie własne na podstawie danych Ministerstwa Finansów.

Kolejną kwestią wartą poruszenia jest koszt długu samorządowego. Nie jest technicznie możliwe zbadanie umów kredytowych, listów emisyjnych obligacji ani innych umów określających oprocentowanie zobowiązań wszystkich jednostek. Dlatego też szacunków średniego „oprocentowania” długu samorządowego dokonano przez przyrównanie prognozowanych wydatków bieżących jednostek na obsługę długu (odsetki i dyskonto) do wysokości ich zadłużenia, pozostającego do spłaty w danym roku. Wykorzystanie w tym celu danych zamieszczonych w wieloletniej prognozie finansowej należy uznać za zasadne, ponieważ wydatki związane $\mathrm{z}$ obsługą długu wydają się łatwiejsze do predykcji niż inne kategorie finansowe, co wynika z zapisów umów określających zobowiązania jednostek. O ile wysokość niektórych prognozowanych kategorii finansowych jednostek ma charakter, ogólnie ujmując, heurystyczny (np. wysokość wpływów z podatków lokalnych w 2020 r.), o tyle wysokość kosztów długu w tym przykładowym roku może być określona (dla długu o oprocentowaniu stałym) lub w sposób relatywnie wiarygodny prognozowana (dla zobowiązań o oprocentowaniu zmiennym).

Większość zobowiązań długoterminowych samorządów charakteryzuje się oprocentowaniem zmiennym, indeksowanym najczęściej do stóp procentowych rynku międzybankowego (głównie WIBORu 1-, 3- lub 6-miesięcznego). Aby przewidzieć wysokość przyszłych stawek międzybankowych, determinujących oprocentowanie instrumentów indeksowanych, w praktyce prognostycznej przyjmuje się za punkt odniesienia inflację, gdyż jej wysokość wpływa bezpo- 
średnio na cenę pieniądza na rynku międzybankowym. Prognoz inflacyjnych z wykorzystaniem zaawansowanych modeli można dokonać na relatywnie krótki okres ${ }^{17}$. Z kolei w długim okresie najczęściej przyjmuje się oczekiwana wartość inflacji na poziomie celu inflacyjnego banku centralnego, który wynosi obecnie $2,5 \%$, a po przystapieniu do strefy euro poziom ten obniży się do $2 \%$ i mniej. Dlatego obserwując spready (rozpiętość) pomiędzy inflacją a poszczególnymi stawkami WIBOR i znając marże odsetkowe poszczególnych samorządowych tytułów dłużnych, planiści w jednostkach samorządu terytorialnego moga z dużą wiarygodnością określić przyszłe odsetki płacone przez jednostki ${ }^{18}$. Wydaje się zatem, że prognozowane wydatki jednostek na obsługę długu można uznać za względnie realistyczne ${ }^{19}$. Szacunkowa średnią wartość oprocentowania długu samorządowego można więc uzyskać, przez porównanie wysokości wydatków (odsetek) z wartoścą długu pozostającego do spłaty w danym roku budżetowym ${ }^{20}$, co przedstawiono na wykresie 8 .

Z wyjątkiem powiatów ziemskich jednostki samorządu terytorialnego w okresie przed sporządzaniem prognozy (lata 2011-2012) ponosiły koszty długu w wysokości 4-5,5\% jego wysokości, przy czym zauważalna była tendencja wzrostowa tej wielkości. Ponownie 2013 r. okazał się rokiem nietypowym, w którym koszty długu były przeciętnie wyższe, co mogło wiązać się z opisywaną wcześniej restrukturyzacją zadłużenia, której przejawem były ponadprzeciętne wartości przychodów i rozchodów samorządowych (porównaj wykres 4). W następnych latach prognozy relacja wydatków na obsługę długu do jego poziomu kształtowała się w przedziale 5-6\%, im dalej zaś w czasie, tym jej wartość zwiększała się do poziomu nawet powyżej 7\%. Od mniej więcej 15 roku prognozy odnotować należy wzrost zróżnicowania oprocentowania wśród poszczególnych szczebli samorządowych. Można zauważyć zarówno zaskakujące spadki kosztów, jak i ich wzrosty, jednakże należy je uznać za wynik możliwego dużego wpływu pojedynczych, nietypowych przypadków - dlatego trudno wnioskować o przeciętnym oprocentowaniu instrumentów długu samorządowego po $2030 \mathrm{r}$.

${ }_{17}$ Prognozy te dokonywane sa przez wiele instytucji, ale za najbardziej wiarygodne należy uznać prognozy Narodowego Banku Polskiego, którego głównym zadaniem jest przeciwdziałanie inflacji, oraz Ministerstwa Finansów, gdyż jego prognozy inflacyjne tworzą założenia do Wieloletniego Planu Finansowego Państwa, który pośrednio określa także kształt planów finansowych całego sektora finansów publicznych, w tym sektora samorządowego.

${ }_{18}$ Taki sposób ustalania prognoz finansowych przez jednostki samorządu terytorialnego sugerowany jest także przez Ministerstwo Finansów, które przedstawia wytyczne w zakresie prognoz, publikując długookresową (do 2040 r.) predykcję dynamiki PKB oraz wskaźnika CPI. Wytyczne dotyczace założeń makroekonomicznych na potrzeby wieloletnich prognoz finansowych jednostek samorzqdu terytorialnego, Ministerstwo Finansów, Warszawa 2012.

${ }^{19}$ Należy zauważyć dodatkowo, że na poziom kosztów długu wpływ mogą mieć także wahania kursów walutowych, jednakże dług samorządowy denominowany jest w większości w złotych, stąd wpływ zmian cen walut na prognozowane wartości wydatków ponoszonych na jego obsługę jest w zasadzie nieznaczny.

${ }^{20}$ Odsetki uzależnione są od wysokości długu, którym obciążona była jednostka, a nie który pozostał po spłacie raty kapitałowej. Dlatego też, aby w sposób wiarygodny wyznaczyć koszt długu, wartość odsetek płaconych w roku $n$ podzielono przez wartość zadłużenia na koniec okresu $n$-1, tj. przez stan zobowiązań, który określa jednocześnie wysokość długu jednostki na początku roku $n$-tego. Skutkiem tego prezentacja kosztów rozpoczyna się od 2011 r. 
Wykres 8

Szacunkowa wartość średnia oprocentowania długu samorządowego w Polsce

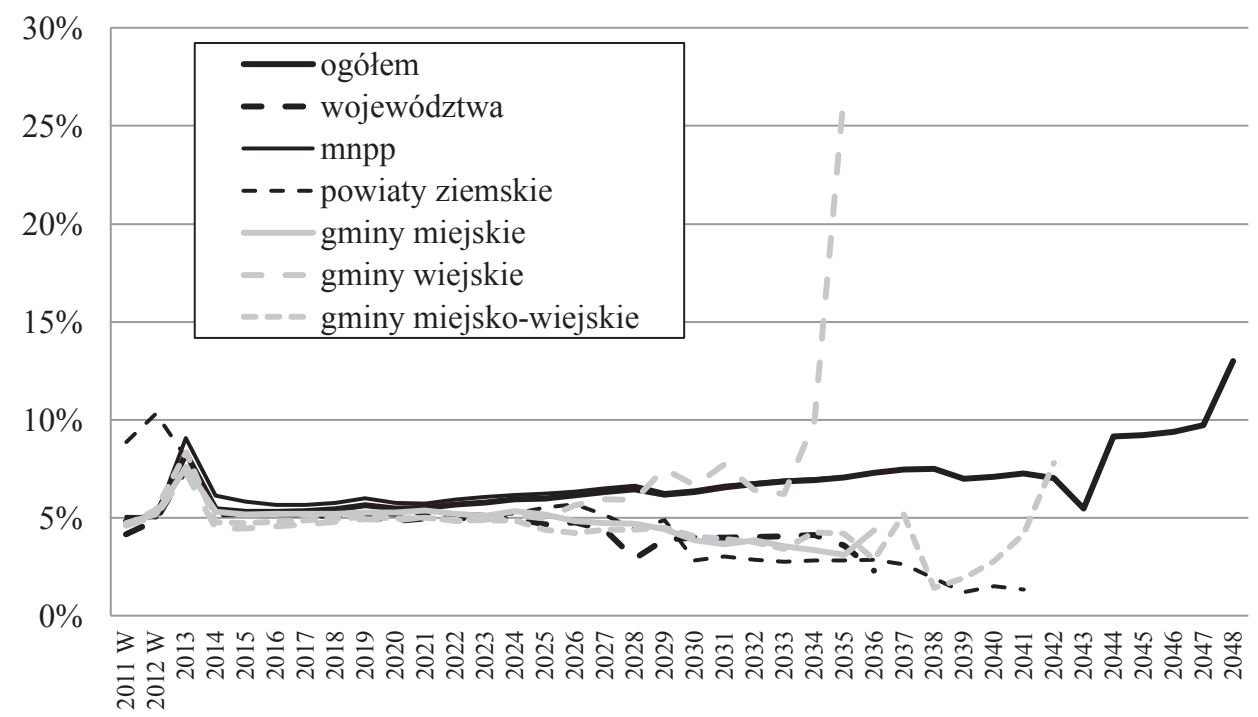

Źródło: opracowanie własne na podstawie danych Ministerstwa Finansów.

Warto również na koniec porównać koszt długu samorządowego z kosztami długu Skarbu Państwa. Według danych Ministerstwa Finansów w latach 2010-2012 koszt długu krajowego kształtował się w przedziale od 5 do $5,5 \%^{21}$. Można zatem stwierdzić, że w okresie przed dokonywaniem prognozy oprocentowanie długu samorządowego było na zbliżonym poziomie co wysokość oprocentowania długu Skarbu Państwa, a nawet niższym. Pozwala to wysunąć wniosek, że z punktu widzenia marż odsetkowych jednostki samorządu terytorialnego jako dłużnicy są postrzegane przez kapitałodawców jako wiarygodne.

\section{PODSUMOWANIE}

W niniejszym artykule przedstawiono tendencje w zakresie zarządzania długiem w jednostkach samorządu terytorialnego w Polsce. Było to możliwe dzięki wykorzystaniu danych $\mathrm{z}$ wieloletnich prognoz finansowych jednostek, które po raz pierwszy zostały zgromadzone i upublicznione przez Ministerstwo Finansów w 2013 r. Wśród wykrytych prawidłowości za najważniejsze należy uznać następujące:

${ }^{21}$ Strategia zarzqdzania dtugiem sektora finansów publicznych w latach 2014-2017, Ministerstwo Finansów, Warszawa 2013, s. 8. 
- dominująca część zadłużenia samorządowego stanowia zobowiązania miast na prawach powiatu i jednocześnie prognozowany termin całkowitej ich spłaty jest przeciętnie najbardziej odległy - najszybciej swoje zadłużenie zamierzają z kolei spłacić gminy miejskie, gminy wiejskie i województwa;

- w pierwszych latach prognozy najsilniej obciążone zadłużeniem (w relacji do dochodów ogółem) planują być województwa, w drugiej kolejności - miasta na prawach powiatu;

- najbardziej zróżnicowaną grupa jednostek pod względem obciążenia długiem sa powiaty ziemskie;

- zmian wysokości zadłużenia planuje dokonać wiele jednostek w roku 2013 - oznacza to zarówno wysokie przychody, świadczące o zaciaganiu długu, jak i wysokie spłaty zadłużenia, w postaci wysokich rozchodów. Świadczy to z jednej strony o wzroście zadłużenia jednostek, ale także o tym, że wiele jednostek zdecydowało się zmniejszyć swój dług, aby sprostać wymogom indywidualnego wskaźnika zadłużenia wchodzacego w życie od 2014 r., czemu towarzyszył także okresowy wzrost kosztów obsługi długu;

- niemal w całym okresie prognozy prognozowana relacja odsetek do ogółu środków publicznych przeznaczanych na obsługę długu kształtuje się na stałym poziomie, ok. $25 \%$, przy czym najwyższy udział odsetek w pierwszych latach prognozy odnotowano w województwach oraz miastach na prawach powiatu; wynikało to przede wszystkim z ich wysokiego zadłużenia oraz relatywnie dłuższego okresu zapadalności ich zobowiązań;

- na podstawie prognozowanych wielkości wydatków bieżących ponoszonych na obsługę długu oszacowano koszty długu samorządowego, które w pierwszych 10 latach prognozy kształtowały się w przedziale mniej więcej 5-6\%; co ważne koszty długu samorządowego w okresie poprzedzającym prognozę były bardzo zbliżone lub nawet niższe do kosztów obsługi długu Skarbu Państwa, co świadczy o postrzeganiu samorządów przez podmioty finansujące w sposób zwrotny za wiarygodne kredytowo na równi ze Skarbem Państwa.

Warto w zakończeniu odnieść się także do zapisów „Strategii zarządzania długiem sektora finansów publicznych" sformułowanej przez Ministerstwo Finansów. Według przedstawionych w niej założeń dług samorządowy będzie zwiększał się do 2014 r., przy czym jego przyrosty będą coraz wolniejsze. Dopiero od 2015 r. Ministerstwo spodziewa się stopniowego spadku zadłużenia samorządowego ${ }^{22}$. Z przedstawionych $\mathrm{w}$ artykule wyników badań wynika, że spadku zadłużenia można się spodziewać już od 2014 r. - na to wskazuja prognozy finansowe samorządów. Wydaje się zatem, że Ministerstwo Finansów w sposób ostrożny podchodzi do planów samorządowych, spodziewając się zmian w WPF uchwalanych na lata 2014+, polegających na zapisaniu w nich wyższych przychodów i zobowiązań niż te, które określone zostały w WPF na lata 2013+, stanowiących źródło danych dla przeprowadzonych w niniejszym artykule badań.

Podsumowując, warto wskazać, że dzięki obowiązkowi sprawozdawczemu w zakresie WPF możliwe stało się przeprowadzanie badań planowania finansowego w samorządach, w tym w zakresie zarządzania długiem. Jeżeli wymo-

${ }^{22}$ Strategia zarzadzania dtugiem..., s. 41. 
gi te zostaną utrzymane w mocy w kolejnych latach, możliwa będzie analiza zmian dokonywanych w planach finansowych. Pozwoli to z jednej strony ocenić skuteczność i stabilność dokonywanych przez samorządy prognoz, a z drugiejumożliwi określanie niektórych przyczyn i skutków dokonywanych zmian.

dr Dorota Wiśniewska

Uniwersytet Ekonomiczny w Poznaniu

dorota.wisniewska@ue.poznan.pl

dr Marcin Wiśniewski

Uniwersytet Ekonomiczny w Poznaniu

marcin.wisniewski@ue.poznan.pl

\title{
TRENDS IN THE LOCAL GOVERNMENT DEBT MANAGEMENT IN POLAND \\ ON THE BASIS OF LONG-TERM FINANCIAL FORECASTS \\ OF LOCAL GOVERNMENT UNITS
}

\begin{abstract}
Sum mary
The considerable growth of Polish local government debt observed recently has resulted in the increasing importance of debt management as part of the overall financial management in local government units. An essential tool in this process is the long-term financial forecast, mandatory since 2010. In 2013 local governments were also obliged to report, in a standardised form, their forecasts, and the first aggregated data have already been published by the Ministry of Finance. Thus, for the first time, trends in the local government debt management in Poland could be analysed. This paper examines the main features of this process as reflected in local governments' financial plans. In particular, the size of the planned debt and its service has been analysed in absolute terms and in relation to the units' income, followed by an analysis of debt repayment schedules and the cost of the debt.
\end{abstract}


Copyright of Journal of Law, Economics and Sociology is the property of Faculty of Law and Administration of Adam Mickiewicz University in Poznan and its content may not be copied or emailed to multiple sites or posted to a listserv without the copyright holder's express written permission. However, users may print, download, or email articles for individual use.

Właścicielem praw autorskich do „Ruchu Prawniczego, Ekonomicznego i Socjologicznego” jest Wydział Prawa i Administracji Uniwersytetu im. Adama Mickiewicza w Poznaniu. Zawartość czasopisma nie może być kopiowana, przesyłana do innych stron internetowych bądź zamieszczana na blogach bez pisemnej zgody wydawcy. Niemniej artykuły można drukować, kopiować lub przesyłać w formie elektronicznej na własny użytek. 